ISSN (Print) : :1412-7601

ISSN (Online) : 2654-8712

Volume 6, No.1 Maret 2020

EKONOBIS

http://www.ekonobis.unram.ac.id

\title{
Profil Potensi Investasi Kabupaten Lombok Timur Tahun 2020
}

\section{Jalaludin.}

Universitas Mataram ARTICLE INFO

\section{Keywords :}

Profile investment, investor, East Lombok Regency

Kata Kunci :

Profil potensi investasi, Investor, kabupaten

Lombok Timur

ABSTRACT : To increases investment activity, each regency include East Lombok Regency try to promote its economic and medly opportunity of investment and easy of variety as well as incentive which is given to investor. The eforts more inportant because East Lombok Regency economy whereas growth into shifting sector, where contribution of agriculture sector was decline. The purpose of the Potential investment profile are to be guidence and information media for anyone at all having an interest related investment in East Lombok.

ABSTRAK: Untuk meningkatkan kegiatan investasi, maka setiap daerah tak terkecuali kabupaten Lombok Timur berusaha untuk mempromosikan potensi ekonomi dan beragam peluang investasi yang dimiliki termasuk berbagai kemudahan dan insentive yang diberikan kepada para investor. Upaya tersebut menjadi semakin penting mengingat perekonomian kabupaten Lombok Timur sedang tumbuh kearah pergeseran sector dimana peran sector pertanian semakin kecil seiring dengan meningkatnya peran sector- sector lain dalam pembentukan PDRB. Profil Potensi Investasi Kabupaten Lombok Timur tahun 2020, disusun dengan harapan dapat menjadi panduan dan media informasi bagi pihak yang berkepentingan dalam kaitannya dengan investasi di Lombok Timur..

Corresponding Author :

Alamat : Program Studi Ekonomi Pembangunan, Fakultas Ekonomi dan Bisnis, Universitas Mataram, Jln. Majapahit No. 62 Mataram.

e-mail: jalaludin@unram.ac.id 


\section{PENDAHULUAN}

\section{Latar Belakang}

Undang- undang No. 32 Tahun 2004 tentang pemerintahan daerah memberikan kewenangan yang luas kepada daerah untuk mengatur dan mengurus sendiri urusan pemerintahan menurut azas otonomi dan tugas perbantuan dengan memperhatikan prinsip demokrasi, pemerataan, keadilan, keistimewaan dan kehususan suatu daerah dalam system Negara Kesatuan Republik Indonesia.

Pelimpahan wewenang yang luas tersebut dimaksudkan untuk mempercepat proses pembangunan di daerah sehingga kesejahteraan masyarakat sebagai tujuan ahir dari pembangunan dapat segera terwujud. Salah satu bentuk kewenangan tersebut adalah daerah tingkat II diberikan keleluasan untuk mengatur dan mengelola perekonomiannya berdasarkan kebutuhan dan kondisi serta potensi daerah masing- masing. Sebagai konsekwensinya, pemerintah daerah memiliki kewenangan dan tanggung jawab yang luas untuk menggali dan mengusahakan segenap potensi daerah yang dimiliki guna mencapai pertumbuhan ekonomi sebagai prasyarat bagi tercpainya kesejahteraan masyarakat.

Berbicara mengenai pertumbuhan ekonomi, maka peran modal/ investasi menjadi sangat penting, karena tampa adanya akumulasi modal/ capital tidaklah mungkin pertumbuhan ekonomi bisa dicapai. Disisi lain optimalisasi pemampaatan sumberdaya (resource) ekonomi yang lain juga seringkali terkendala akibat keterbatasan sumber pembiayaan/ investasi sehingga banyak sumberdaya yang menganggur/ belum dimampaatkan karena ketiadaan modal untuk mengelolanya.

Untuk meningkatkan kegiatan investasi, maka setiap daerah berlomba untuk menyebarluaskan informasi mengenai potensi ekonomi dan peluang investasi yang dimiliki termasuk berbagai kemudahan dan insentive yang diberikan kepada para investor. Semua ini dilakukan guna menarik para investor untuk berinvestasi di daerahnya. Hal ini menjadi semakin penting, mengingat perekonomian kabupaten Lombok Timur sedang tumbuh kearah pergeseran sector dimana peran sector pertanian semakin kecil seiring dengan meningkatnya peran sector- sector lainnya diluar sktor pertania dalam pembentukan PDRB. Untuk lebih 
mempercepat pertumbuhan ekonomi sektoral, maka kegiatan investasi diberbagai sector terutama sector pertanaian, industri, pariwisata dan sector pertambangan perlu di tingkatkan.

Terkait dengan hal tersebut di atas, maka tulisan ni mencoba untuk mengangkat "Profil Potensi Investasi Kabupaten Lombok Timur tahun 2020" dengan harapan dapat menjadi panduan dan media informasi bagi pihak yang berkepentingan/ stake holder tarkait. Secara husus tulisan mengenai profil investasi ini bertujuan untuk :

1. Mendiskripsikan berbagai potensi investasi yang ada di kabupaten Lombok Timur berdasarkan sectorsector ekonomi unggulan.

2. Sebagai instrumen atau media perluasan akses informasi tentang perekonomian daerah.

3. Memberikan informasi dan panduan bagi para investor yang ingin berinvestasi atau menanamkan modalnya di kabupaten Lombok Timur mengenai berbagai peluang dan kemudahan berinvestasi di Kabupaten Lombok Timur.

4. Sebagai media koordinasi untuk menunjang pelaksanaan program pembangunan ekonomi lintas sector.

5. Sebaga bahan referensi bagi pihakpihak yang berkepentingan yang ingin mendalami masalah investasi hususnya yang ada di Lombok Timur.

Selain tujuan di atas, penyusunan profil Investasi ini juga dimaksudkan sebagai refrensi atau rujukan bagi pemerintah dalam pengambilan keputusan atau kebijakan khususnya yang berkaitan dengan investasi

Penyajian profile investasi ini meliputi seluruh wilayah kabupaten Lombok Timur. Dengan mempertimbangkan kebijakan dan skala prioritas dalam pengembangan ekonomi daerah, maka untuk sementara penyusunan buku profil potensi investasi ini hanya mencakup tiga sector yaitu sector pertanian dalam arti luas, sector industri, dan sector pertambangan.

\section{KAJIAN PUSTAKA}

\section{Potensi Dan Peluang Investasi}

\section{Sektor Pertanian}

Hingga kini sector pertanian masih memegang peranan yang cukup penting dalam perekonomian Daerah Kabupaten Timur. Hal ini ditandai dengan relative besarnya kontribusi sector ini dalam pembentukan Product Domestic Regional 
Bruto (PDRB). Walaupun sharenya dalam PDRB mengalami penurunan, namun sector ini masih menjadi penyumbang terbesar dengan rata- rata 41,93 persen dalam kurun waktu lima tahun terahir.

Adanya fakta di atas menunjukkan bahwa struktur ekonomi Kabupaten Lombok Timur masih mengandalkan dukungan sector pertanian sebagai sector basis terlebih sebagian besar penduduk menggantungkan hidupnya pada sector ini. Menyadari kenyataan ini pemerintah daerah melalui dinas- dinas terkait terus berupaya meningkatkan dan mengembangkan sector pertanian baik secara ekstensifikasi, intensifikasi, diversifikasi dan rehabilitasi termasuk dengan mengundang para investor untuk mau berinvestasi pada sector ini.

Disisi lain dukungan lahan dan iklim yang cukup kondusip menjadi pertimbangan tersendiri bagi pemerintah sebelum ahirnya menetapkan sector ini sebagai sector prioritas dalam pembangunan ekonomi. Sebagai salah satu sector prioritas, maka keberadaan sector pertanian (dalam arti luas) perlu mendapat perhatian baik dari segi kebijakan, dukungan lahan dan pendanaan (investasi) yang memadai sehingga kontribusi dari sector ini benarbenar dapat menjadi sokoguru perekonomian daerah sekaligus

memberikan kesejahteraan bagi masyarakat banyak.

Subsektor tanaman bahan makanan yang meliputi padi dan palawija, sayur- sayuran dan buah- buahan, merupakan komoditas potensial untuk dikembangkan. Bahkan untuk komoditas jagung kabupaten lombok timur tercatat sebagai produsen terbesar di Nusa tenggara Barat baik dari segi total produksi, maupun dari segi produktifitas perhektar lahannya. Disamping itu bila dilihat dari cost benefit ratio, berdasarkan survey struktur ongkos usaha yang telah dilakukan oleh BPS ternyata proporsi biaya rata- rata per-hektar Ubi Kayu, Ubi Jalar dan Jagung adalah yang paling rendah yaitu berkisar antara 18- 26 persen. Bandingkan dengan kacang tanah dan kedelai yang mencapai $28-42$ persen, bahkan padi yang paling tinggi mencapai 47 - 56 persen. Dengan demikian kedua komoditas ini memiliki prospek yang bagus untuk dikembangkan sekaligus menjadi peluang bagi para investor untuk menanamkan modalnya mengingat selain dukungan lahan yang cukup, juga pemasaran dari kedua komoditas ini juga masih prospektif.

Sementara subsektor tanaman perkebunan sebagian besar 
memampaatkan lahan sawah untuk perkebunan musiman seperti tembakau. Sedangkan untuk tanaman tahunan dan jangka panjang diusahakan di lahan kering dan terkonsentrasi di tempat- tempat tertentu. Berdasarkan data statistik tercatat bahwa luas lahan untuk areal perkebunan yang ada di Kabupaten Lombok Timur 105771 Ha. dan baru di mampaatkan sekitar 42.364,20 $\mathrm{Ha}$. Dengan demikian masih tersisisa lahan perkebunan yang belum dimampaatkan sebesar 63.407,30 Ha. Dengan kata lain dapat dikatakan bahwa tanaman perkebunan di Kabupaten Lombok Timur baru memampaatkan sekitar 40 persen dari total luas lahan yang tersedia dan ini merupakan tantangan sekaligus peluang bagi para investor untuk berinvestasi pada subsektor perkebunan di Kabupaten Lombok Timur.

Adapun jenis tanaman perkebunan yang dapat dibudidayakan adalah Tembakau, Kakao, Vanili, Kopi, Kelapa dan sebagainya yang mana beberapa diantaranya seperti Tembakau Virginia dan Kakao, selain merupakan produk unggulan daerah, sekaligus juga menjadi komoditas unggulan dan kebanggaan Propinsi Nusa Tenggara Barat.

Untuk subsektor peternakan, masih didomonasi oleh usaha tani ternak sapi dan Kambing. Pengusahaannyapun masih bersipat sampingan dan belum ada yang mengusahakannya secara propesional. Pengusahaan peternakan seperti ini tentu kurang memberikan hasil yang maksimal bagi para petani, namun hal ini terjadi karena keterbatasan modal yang dimiliki sedrta masih kurangnya pembinaan yang dilakukan oleh dinas/ instansi terkait. Padahal kalau pengelolaan usaha tani ternak ini dikelola secara propesional dan bersipat masal misalnya dengan pola penggemukan sapi dengan system bagi hasil maka keuntungan yang akan diterima baik oleh para petani maupun oleh pemerintah akan jauh lebih besar. Untuk mewujudkan semua ini memang diperlukan modal dan good will dari pemerintah sehingga kedepan Kabupaten Lombok Timur bisa menjadi pensupply daging tidak hanya untuk kebutuhan daerah sendiri tapi juga untuk daerah lain. Harapan ini bukannya tampa alasan, mengingat lahan untuk pemeliharaan Sapi dan Kambing yang masih tersedia cukup luas terutama di kecamatan- kecamatan pinggiran seperti Suela, Sembalun, Wanasaba, Aikmel dan Sambelia.

Selain sapi dan kambing peluang investasi juga terbuka pada peternakan ayam potong, ayam petelur dan 
peternakan itik. Sebagai gambaran bahwa produksi telur Unggas di Kabupaten Lombok Timur pada tahun 2018 sebesar $935.423 \mathrm{Kg}$ menurun bila dibandingkan dengan tahun 2017 yang besarnya 978.606 Kg. Sementara perkiraan kebutuhan telur dengan assumsi konsumsi perkapita perminggu 1 butir (sekitar 0,06 Kg) dengan jumlah penduduk 1.192.110

Jiwa, berarti jumlah kebutuhan telur pertahun tidak kurang dari 3.306,9 ton. Dengan demikian terjadi defisit sekitar 2.371,5 ton. Berdasarkan data ini walaupun dengan perhitungan kasar, setidaknya dapat memberikan gambaran mengenai peluang investasi pada bidang peternakan terutama pada bidang usaha peningkatan produksi telur (usaha ternak ayam petelur dan itik).

Sedangkan untuk pengembangan subsektor perikanan, Lombok Timur memiliki luas daerah pantai sekitar $1.874,33 \mathrm{Km}^{2}$ yang terbentang dari bagian utara ke arah timur hingga ke arah bagian selatan, merupakan areal yang cukup potensial bagi usaha budidaya perikanan. Secara keseluruhan potensi areal untuk pengembangan budidaya laut yang ada di Kabupaten Lombok Timur sekitar 5.803,08 Ha. dan baru dimampaatkan sekitar $1.543,25 \mathrm{Ha}$. atau sekitar 26,59 persen.
Hal ini menunjukkan bahwa pemampaatan potensi budidaya laut masih sangat kurang bahkan sebagian besar pemampaatan yang sangat kecil ini digunakan untuk budidaya mutiara. sementara budidaya kerapu, lobster dan rumput laut baru berkisar 1- 2 persen. Demikian pula halnya dengan potensi pengembangan budidaya tripang dan kerang- kerangan yang sama sekali belum dimampaatkan yang kesemuanya ini jelas merupakan tantangan sekaligus peluang investasi yang cukup prospektif mengingat hasil budidaya laut memiliki pangsa pasar yang cukup luas tidak hanya lingkup regional maupun nasional bahkan telah merambah ke pasaran internasional dengan harga yang lumayan tinggi.

Selain budidaya perikanan laut, potensi areal perikanan di kabupaten Lombok Timur juga berupa budidaya perikanan tambak, sawah dan kolam. Pada tahun 2008 potensi areal perikanan tambak tersedia $3.500,00 \mathrm{Ha}$, perikanan air tawar (sawah) 3.138,00 Ha dan Kolam $1.771,35 \mathrm{Ha}$. Data ini menunjukkan bahwa selain pada budidaya laut, potensi investasi bagi para investor juga terbuka luas pada perikanan air tawar dengan total potensi pengembangan sekitar $8.409,35 \mathrm{Ha}$.

\section{Sektor Pertambangan}


Tidak seperti halnya dengan sector pertanian, kegiatan usaha di sector pertambangan masih sangat terbatas yaitu masih pada bahan tambang/galian $C$ berupa batu apung, batu bangunan, sirtu dan tanah liat serta tanah urug. Semua bahan tambang tersebut diusahakan dalam skala yang masih kecil untuk memenuhi kebutuhan konstruksi local kecuali batu apung yang menjadi komoditas andalan dan diusahakan secara luas di beberapa kecamatan di Kabupaten Lombok Timur dimana pemasarannya juga untuk diekspor/ di antar pulaukan ke pulau Jawa.

Penambangan batu apung hingga saat ini masih memberikan harapan yang cerah mengingat potensi areal yang cukup luas dan tersebar di enam kecamatan yaitun Sakra Timur, Terara, Labuhan haji, Suralaga, Sikur, Masbagik dan Pringgasela, serta pemasarannya yang terus mengalami peningkatan. Hingga tahun 2018 terdapat 359 perusahaan/ usaha dengan total investasi sebesar Rp.14.970.000.000,00.

\section{Sektor Industri}

Dukungan sector industri terhadap pengembangan dan kemajuan perekonomian daerah sangat penting. Hal ini selain disebabkan karena peran dari sector pertanian yang semakin menurun dari tahun ke tahun, juga sector industri menjadikan nilai tambah dari sector pertanian semakin meningkat. Disis lain peran sector industri yang semakin menonjol dalam perekonomian daerah juga bisa menjadi indikasi dari kemajuan ekonomi suatu daerah.

Mengingat peran sector pertanian yang masih dominan dalam pembentukan Product domestic Regional Bruto Kabupaten Lombok Timur maka kondisi tersebut menyiratkan peluang investasi yang terbuka luas pada sector yang bersangkutan. Artinya bahwa potensi produk- produk pertanian yang dimiliki seperti ubi kayu, jagung bawang merah dan bawang putih serta beberapa produk perikanan yang menjadi andalan lainnya, sesungguhnya merupakan peluang bagi para investor untuk melakukan investasi pada industri pengolahan produk tersebut sehingga bisa memberikan nilai tambah yang lebih besar.

Disamping itu karena jumlah penduduknya yang relatif banyak dibanding dengan daerah lain, Kabupaten Lombok Timur merupakan pangsa pasar produk- produk industri daerah lain seperti krepik singkong, tepung kanji, tepung beras, tepung jagung, kerupuk udang, keripik pisang telur asin, makanan ternak dan berbagai macam produk 
industri olahan lainnya yang bahan bakunya justru berasal dari kabuapten Lombok timur. Kondisi ini sesungguhnya merupakan peluang investasi yang sangat menguntungkan karena kalau produkproduk industri tersebut bisa diproduksi ditempat, maka biaya bisa lebih murah karena bahan baku tersedia melimpah dan permintaannya sudah jelas karena jumlah penduduk Kabupaten Lombok Timur yang cukup besar dibandingkan dengan daerah lain di NTB.

Berdasarkan kenyataan dan penjelasan di atas, maka dapat dikatakan bahwa peluang investasi pada sector industri di Kabupaten Lombok Timur terbuka luas terutama pada bidang kegiatan yang terkait dengan pengolahan hasil- hasil pertanian seperti ; Industri tepung ubi kayu dan hasil olahan dari ubi kayu lainnya, Industri gula kelapa/ gula aren, Industri makanan ternak, Industri garam beryodium dan industri pengalengan ikan serta industri pengolahan rumput laut dan sebagainya.

Demikian pula seiring dengan perkembangan industri pariwisata yang diperkirakan akan terus meningkat di masa depan, maka potensi investasi yang menarek juga ada pada pengembangan dan peningkatan kapasitas industri cendera mata (kain tenun tradisional, anyam- anyaman, grabah dan lain sebagainya yang memiliki keunikan tersendiri. Peluang pemasaran ke beberapa daerah tujuan wisata, bahkan ekspor ke luar negeri terbuka lebar sementara untuk konsumen local dari kemungkinan timbulnya permintaan efektif akibat kemajuan pariwisata tersebut sangat terbuka pada investasi pengolahan produk- produk makanan jadi dengan bahan baku yang melimpah di wilayah setempat.

\section{PEMBAHASAN}

\section{Analisis Kebijakan Investasi Kabupaten Lombok Timur}

Selama hamper dua decade pelaksanaan otonomi daerah yang digulirkan sejak tahun 2001, telah terjadi banyak perubahan dalam tata pemerintahan di tingkat local/ daerah. Banyak upaya telah dilakukan oleh pemerintah daerah (Pemda) untuk pembenahan, mulai dari tata kelembagaan pemerintahan, perencanaan perekonomian derah dan pelayanan public/ kemasyarakatan lainnya termasuk menciptakan iklim yang kondusif bagi kegiatan investasi.

Disisi lain, dengan berbagai alasan, tidak sedikit justru dijumpai praktikpraktik negatif dalam penyelenggaraan pemerintahan dan pelayanan publik yang 
justru mengurangi daya saing investasi daerah. Keterbatasan pemda dalam melakukan pembiayaan pembangunan perekonomian daerah, sering dijadikan alasan untuk mengeluarkan kebijakan yang justru kontraproduktif terhadap penciptaan daya saing investasi. Padahal dalam konteks pembangunan regional, investasi memegang peran penting untuk mendorong pertumbuhan ekonomi daerah. Pemerintah daerah harus berupaya keras untuk mendorong agar investasi sebanyak mungkin bisa masuk ke daerahnya. Hanya daerah- daerah yang memiliki daya saing investasi yang baik yang akan mendapatkan peluang investasi yang lebih besar.

Terkait dengan kebijakan investasi di kabupaten Lombok timur, dengan menyadari akan peran sektoral perekonomian daerah dimana kontribusi sektor pertanian masih cukup signifikan terhadap pembentukan Produk Domestik regional Bruto (PDRB), maka kebijakan pengembangan investasi/ penanaman modal di Kabupaten Lombok Timur seyogyanya diarahkan untuk peningkatan dan pengembangan sektor pertanian. Namun demikian bukan berarti sektor lain bisa diabaikan, justru pengembangan investasi pada sektor- sektor lain terutama sektor industri dan pertambangan serta sektor pariwisata sangat penting untuk diperhatikan.

Dari sisi tujuan, penekanan kebijakan investasi sebaiknya diarahkan untuk meningkatan nilai tambah, penyediaan dan perluasan kesemptan kerja dan penyediaan barang serta jasa untuk kebutuhan pembangunan daerah. Prioritas utama diarahkan pada perbaikan ekonomi rakyat dengan menambah kapasitas produksi barang dan jasa serta mengupayakan pendistribusiannya secara merata.

Untuk menjaga kesinambungan dalam pelaksanaan pembangunan daerah, maka kebijakan pengembangan ekonomi sektoral perlu memperhatikan dan mempertimbangkan keseimbangan dan kelestarian lingkungan. Terlebih menyangkut pengembangan investasi pada sektor pertambangan dimana sektor ini sangat rentan terhadap kerusakan dan penurunan kualitas lingkungan. Demikian pula terhadap pengembangan perikanan terutama perikanan laut, Pemerintah daerah harus dapat menjamin bahwa eksplorasi yang dilakukan benar- benar tidak merusak lingkungan dan biota laut yang ada disekitarnya.

Demikian pula dengan pengembangan investasi pada sektor industri dan pariwisata sebagai salah satu 
sektor alternatip yang cukup menjanjikan, perlu dilakukan upaya pembinaan dan pembinaan dengan membuat aturan yang jelas dan transparan. sehingga kedepan bisa memberikan kontribusi yang lebih besar terhadap perekonomian daerah. Disamping itu dalam mengembangkan peluang investasi pada sektor industri dan pariwisata termasuk juga sektor lainnya perlu mempertimbangkan dukungan atau ketersedian bahan baku/ faktor produksi dari sisi suplay dan kebutuhan/ kecenderungan pasar dari sisi demand. Hal ini penting mengingat eksistensi sebuah kegiatan investasi sangat tergantung pada kontinewitas/ kesinambungan produksi disatu sisi dan keberlanjutan pemasaran pada sisi lainnya.

Dengan demikian, untuk mengembangkan kegiatan investasi di kabupaten Lombok Timur paling tidak perlu dikembangkan tiga langkah strategis yaitu : 1) mengembangkan perekonomian yang berorientasi global dengan membangun keunggulan competitive berdasarkan keunggulan komparative sebagai daerah agraris dan maritime yang disesuaikan dengan produk unggulan daerah, 2). Mengembangkan kebijakan industri, perdagangan dan investasi dalam rangka meningkatkan daya saing investasi dengan membuka aksesibilitas yang sama terhadap kesempatan kerja dan berusaha bagi segenap masyarakat dan 3). Melakukan penataan terhadap kelembagaan pelayanan publik termasuk Badan Usaha Milik Daerah (BUMD) secara efisien, transparan dan profesional.

\section{KESIMPULAN DAN SARAN}

\section{Kesimpulan}

1. Pembangunan ekonomi masih menjadi focus utama pembangunan baik dalam lingkup nasional maupun regional. Hal ini terjadi mengingat ukuran keberhasilan pembangunan masih mengacu pada pencapaian pertumbuhan ekonomi yang identik dengan peningkatan pendapatan/ kesejahteraan masyarakat. Dengan kata lain pembangunan daerah dianggap berhasil apabila pendapatan atau kesejahteraan masyarakat meningkat dan dianggap gagal bila terjadi sebaliknya.

2. Di era otonomi daerah sekarang ini pembangunan ekonomi daerah semakin mendapat perhatian tersendiri bagi para pengambil kebijakan karena pemerintah daerah mempunyai kewenangan 
yang luas untuk menentukan tujuan dan sasaran pembangunan yang ingin dicapai. Demikian pula halnya dengan pemerintah Kabupaten Lombok Timur dimana peningkatan kesejahteraan masyarakat merupakan salah satu agenda utama pembangunan yang dilaksanakan sebagaimana yang tertuang dalam Renstra tahun 2015- 20020.

3. Berbagai program dan kegiatan pembangunan ekonomi di berbagai bidang dan sector telah dilaksanakan dan akan terus berlanjut. Demikian pula berbagai fasilitas untuk menunjang kegiatan ekonomi telah dan sedang dibangun seperti pasar, pusat pertokoan, termasuk rehabilitasi dan pengadaan infrastruktur penunjangnya trmasuk didalamnya pembangunan sarana dan prasarana transportasi. Semua wilayah telah terhubung dengan prasarana jalan dan alat tranportasi yang cukup memadai, telekomonikasi, lembaga keuangan dan berbagai fasilitas penunjang kegiatan ekonomi lainnya serta fasilitas umum pelayanan social juga tersebar secara merata.

4. Disamping itu pemerintah terus berupaya untuk meningkatkan kapasitas perekonomiannya melalui diversifikasi program dan kegiatan investasi termasuk dengan mengundang atau menawarkan peluang investasi kepada para investor baik local/ domestik maupun asing. Semua ini dimaksudkan agar pertumbuhan ekonomi yang telah dicapai dapat dipertahankan bahkan bisa ditingkatkan.

5. Peluang investasi yang cukup potensial di kabupaten Lombok timur terdapat pada berbagai bidang kegiatan dan sector ekonomi. Pada sector pertanian misalnya pada kegiatan usaha tani pengembangan dan peningkatan produksi palawija dan hortikultura, produk perkebunan seperti tembakau, vanili, kakao, kelapa, dan yang takkalah menariknya adalah usaha tani perikanan laut seperti budidaya mutiara, rumput laut, lobster dan usaha penangkapan ikan lainnya. Sedangkan pada sector industri, peluang investasi yang cukup 
menjanjikan terletak pada pengolahan hasil- hasil pertanian dan industri kerajinan penunjang pariwisata seperti kerajinan gerabah, tenun ikat tradisional, industri anyam- anyaman dan lain sebagainya.

\section{Saran.}

1. Banyak pertimbangan yang dilakukan oleh para investor sebelum ahirnya keputusan berinvestasi diambil. Salah satu diantaranya adalah kejelasan mengenai arah kebijakan investasi daerah, termasuk didalamnya insentif dan kemudahan perizinan dan prosedur yang tidak berbelitbeli/ rumit. Semua ini semestinya dibuat dalam sebuah kebijakan investasi yang jelas yang bisa diakses dan dipahami oleh semua fihak termasuk oleh para investor sendiri. Namun sayangnya hal ini belum maksimal dilakukan oleh pemda Lombok Timur. Oleh karena itu kedepan pihak pemda harus memiliki kebijakan dan tujuan investasi yang jelas serta strategi bagaimana mencapai tujuan dimaksud.

2. Ketersediaan data termasuk kelengkapannya sangat penting, terlebih yang menyangkut data atau informasi mengenai kegiatan investasi. Karena tampa adanya data yang cukup reperesentastif dan valid akan berdampak terhadap kejelasan masa depan dari investasi yang akan dilakukan. Kenyataan menunjukkan bahwa informasi mengenai kegiatan investasi di Kabupaten Lombok timur belum tericord atau terkonfilasi dengan baik sehingga kedepan pihak- pihak yang terkait terutama Bagian PMLH Setda Lombok Timur perlu melakukan konfilasi terhadap informasi/ datadata yang berkaitan dengan kegiatan investasi.

3. Disamping itu para investor akan lebih tertarik untuk melakukan investasi terhadap suatu bidang/ kegiatan investasi yang tersedia informasi mengenai untung ruginya. Dengan kata lain diperlukan adanya studi mengenai kelayakan bisnis pada masingmasing kegiatan investasi. Untuk itu pihak pemda seyogyanya memperhatikan hal ini sehingga kedepan masing- masing produk/ kegiatan usaha yang akan ditawarkan sudah memiliki studi 
kelayakan bisnis, agar iklim investasi semakin menggairahkan karena memiliki informasi yang cukup lengkap.

\section{DAFTAR PUSTAKA}

Anonimous, 2015; Daya saing investasi kabupaten/ kota di Indonesia; persepsi dunia usaha, kerjasama KPPOD, USAID dan Asia Foundation 2019; Data perkembangan Perusahaan PMDN dan PMA di Propinsi NTB,

BKPM Propinsi NTB. 2017 : Komoditi tanaman produksi unggulan dan andalan serta keadaan

flora dan faunan Taman Nasional Gunung Rinjani, Dinas Kehutanan kabuptaten Lombok Timur.

2019 : Lombok Timur Dalam Angka, 2009, BPS Lotim. 2019 : Nusa Tenggara Barat Dalam Angka, 2009, BPS NTB. , 2015 : Profil Potensi Investasi kabupaten Lombok Timur, kerjasama BPMLH dan BPS Lombok Timur. 2019 : PDRB kabupaten Lombok Timur, BPS Lombok Timur. 